\title{
IMPLIKASI POLITIK PENEGAKAN HUKUM PIDANA DALAM UNDANG-UNDANG NOMOR 32 TAHUN 2009TENTANG PERLINDUNGAN DAN PENGELOLAAN LINGKUNGAN HIDUP TERHADAP UPAYA PENEGAKAN HUKUM LINGKUNGAN HIDUP
}

\author{
David Aprizon Putra \\ Universitas Terbuka \\ Jalan Sadang Raya Lingkar Barat Bengkulu \\ Email: David.Aprizon@gmail.com
}

\begin{abstract}
Since 1982 in Law Number 4 of 1982 concerning Environmental Management Principles which was later amended in 1997 to become Law Number 27 of 1997 concerning Environmental Management, legal politics regarding criminal law policy has been carried out. Law Number 32 of 2009 concerning Protection and Management of the Environment (UUPPLH) as the latest generation, has included criminal provisions in Chapter XV, which consists of 23 articles. The results of the study show that criminal law enforcement against formal offenses has a special procedural law, because it relates to the principle of ultimum remedium, meaning that the use of criminal law against formal offenses must wait until administrative law enforcement is declared ineffective. In order to avoid difficulties in enforcing environmental law that is sometimes used by certain elites to seek profits by looking at the gap in the weak regulations in the laws and regulations, the legislation, especially regarding formal law, must be clearly arranged, firm, not multiple interpretations.
\end{abstract}

Keywords: Politic Criminal Law Enforcement, Environmental Law Enforcement

\begin{abstract}
Abstrak: Sejak tahun 1982 dalam Undang-Undang Nomor 4 Tahun 1982 tentang Pokok-Pokok Pengelolaan Lingkungan Hidup yang kemudian diubah pada tahun 1997 menjadi Undang-Undang Nomor 27 Tahun 1997 tentang Pengelolaan Lingkungan Hidup, politik hukum mengenai kebijakan hukum pidana telah dilakukan. Undang-Undang Nomor 32 Tahun 2009 tentang Perlindungan dan Pengelolaan Lingkungan Hidup (UUPPLH) sebagai generasi terbaru, telah memasukkan ketentuan pidana dalam Bab XV, yang terdiri dari 23 pasal. Hasil penelitian menunjukkan bahwa penegakan hukum pidana terhadap delik formal memiliki hukum acara khusus, karena berkaitan dengan asas ultimum remedium, mengandung makna bahwa pendayagunaan hukum pidana terhadap delik formal harus menunggu sampai penegakan hukum administrasi dinyatakan sudah tidak efektif lagi. Untuk menghindari kesulitan dalam penegakan hukum lingkungan yang terkadang dimanfaatkan oleh elit tertentu untuk mencari keuntungan dengan melihat celah lemahnya regulasi pada peraturan perundang-undangan tersebut, maka peraturan perundang-undangan khususnya tentang hukum formal harus disusun secara jelas, tegas, tidak multitafsir.
\end{abstract}

Kata kunci: Poltik Penegakan Hukum Pidana, Penegakan Hukum Lingkungan Hidup 
AL-IMARAH: Jurnal Pemerintahan dan Politik Islam Vol. 3, No. 1, 2018

\section{Pendahuluan}

Lingkungan hidup yang baik dan sehat merupakan hak asasi setiap warganegara Indonesia sebagaimana diamanatkan dalam Pasal 28H ayat (1) Undang-Undang Dasar Negara Republik Indonesia Tahun 1945 (selanjutnya disebut UUD 1945). ${ }^{1}$ Pemanasan global yang semakin meningkat mengakibatkan perubahan iklim sehingga memperparah penurunan kualitas lingkungan hidup karena itu perlu dilakukan perlindungan dan pengelolaan lingkungan hidup.

Pembahasan masalah lingkungan membawa kita pada masalah yang rumit, keterkaitan beberapa faktor dan masalah serta persepsi baru yang mengharuskan kita untuk meninggalkan pandangan-pandangan yang sudah dianggap usang (obstinate). ${ }^{2}$ Perkembangan ini dengan segera membawa kita pada suatu persoalan pokok penting, yaitu cara bagaimana sistem hukum harus mampu menjawab secara efektif persoalan yang timbul dari benturan-benturan kepentingan yang timbul dari pemanfaatan lingkungan yang terjadi akhir-akhir ini. $^{3}$ itu artinya bahwa pemerintah harus mampu membuat suatu pilihan politik hukum yang mampu menciptakan sistem hukum lingkungan yang

${ }^{1}$ Pasal 28H ayat (1) UUD 1945 : "Setiap orang berhak hidup sejahtera lahir dan batin, bertempat tinggal, dan medapatkan lingkungan hidup baik dan sehat serta berhak memperoleh pelayanan kesehatan"

2 Daud Silalahi, Masalah Pengelolaan Lingkungan Hidup, Edisi Ketiga, Alumni, Bandung, 2001, h. 1 ${ }^{3}$ Daud Silalahi, Masalah... kuat dan efektif dalam menyelesaikan setiap permasalahannya.

Undang-Undang Nomor 4 Tahun 1982 tentang Ketentuan-Ketentuan Pokok Pengelolaan Lingkungan Hidup (selanjutnya disebut UUPPLH 1982) merupakan langkah awal kebijakan untuk penegakan hukum lingkungan hidup di Indonesia. UUPPLH 1982 memuat prinsip-prinsip pengelolaan lingkungan hidup yang berfungsi memberikan arahan (direction)bagi sistem hukum lingkungan nasional, dan setelah 15 tahun akhirnya undang-undang ini pun dicabut karena dianggap kurang sesuai agar terwujud pembangunan berkelanjutan seperti apa yang dicitakan yaitu dengan Undang-Undang tentang Pengelolaan Lingkungan Hidup Undang-Undang Nomor 23 Tahun 1997 (selanjutnya disebut UUPPLH 1997) dan diganti lagi oleh Undang-Undang Nomor 32 Tahun 2009 (selanjutnya disebut UUPPLH 2009)dengan alasan agar lebih menjamin kepastian hukum dan memberikan perlindungan terhadap hak setiap orang untuk mendapatkan lingkungan hidup yang baik dan sehat, melalui penjatuhan sanksi pidana yang cukup berat di dalam Undang-Undang Nomor 32 Tahun 2009.

UUPPLH 1982 menempatkan penegakan hukum pidana dalam penegakan hukum lingkungan hidup hanya sebagai ultimum remidium, sehingga isi penegakan sanksi pidananya tidak dominan. Asas ultimum remedium dalam penjelasan UUPPLH 1982, 
ternyata sangat kurang jelas dan tegas. berlangsung dalam satu wadah struktur politik, Penjelasan umum sesungguhnya merupakan sosial, ekonomi,dan budaya pada keadaan upaya memperjelas makna dari konsideran tertentu. ${ }^{5}$

suatu undang-undang. Dalam konsideran

Pada dasarnya, pengertian pemidanaan mengandung nilai-nilai filosofis dari suatu undang-undang. Dengan demikian sesungguhnya penjelasan umum merupakan suatu upaya dari pembentuk undang-undang atau legislator untuk mem-pertegas nilai-nilai filosofis yang terdapat dalam suatu konsideran. Nilai-nilai filosofi dalam konsideran suatu undangundang terkonkritisasi pada batang tubuh berupa pasal-pasal dari undang-undang tersebut. $^{4}$

Kelemahan konsep asas subsidiaritas dalam perumusan pada UUPPLH 1982 mengakibatkan penghapusan asas subsidiaritas. Dalam UUPPLH 1997 asas subsiaritas diganti dengan asas ultimum remedium, yang dibatasi terhadap delik formil tertentu, yaitu pelanggaran baku mutu air limbah, emisi, dan gangguan saja. Selebihnya terhadap delik formil hukum pidana difungsikan sebagai premum remedium. Terdapat minimal empat dimensi yang dapat mempengaruhi kualitas penegakan hukum lingkungan yaitu adanya Undang-undang lingkungan secara nyata, pelanggar hukumnya sendiri, korban (masyarakat), dan aparat penegak hukum, dimana keempat dimensi tersebut bersifat saling mempengaruhi dan

${ }^{4}$ Syahrul Machmud, Penegakan Hukum Lingkungan Indonesia, Graha Ilmu, Yogyakarta, 2011, h. 169.

dalam suatu peraturan perundang-undangan sangat penting. Hal ini telah dimasukkan dalam undang-undang penegakan hukum lingkungan dengan adanya ketentuan pidana yang tercakup dalam undang-undang tentang pengelolaan lingkungan hidup. UUPPLH 2009 telah memasukkan ketentuan-ketentuan pidananya dalam Bab XV, yang terdiri dari 23 pasal, dimulai dari Pasal 97 sampai dengan Pasal 120 UUPPLH. Ketentuan-ketentuan pemidanaan ini jauh lebih lengkap dan rinci bila dibandingkan dengan UUPLH.

Permasalahan lingkungan merupakan permasalahan yang kompleks dan menarik untuk dikaji mendalam, dalam penelitian ini penulis akan mengkaji implikasi politik hukum yang dipilih UUPPLH terkait pengaturan penegakan hukum pidana terhadap penegakan hukum lingkungan di Indonesia untuk saat ini dan masa yang akan datang.

\section{a. Identifikasi Masalah}

Adapun permasalahan yang diangkat dalam penelitian ini adalah :

1. Bagaimana implikasi politik penegakan hukum pidana dalam undang-undang nomor 32 tahun 2009 tentang perlindungan dan pengelolaan

${ }^{5}$ I.S Susanto, Pemahaman Kritis Terhadap Realita Sosial, Majalah Masalah-Masalah Hukum, Nomor 9 Tahun 1992 
lingkungan hidup terhadap upaya penegakan hukum lingkungan hidup Indonesia saat ini ?

2. Bagaimana implikasi politik penegakan hukum pidana dalam undang-undang nomor 32 tahun 2009 (tentang perlindungan dan pengelolaan lingkungan hidup) dan RUU KUHP terhadap upaya penegakan hukum lingkungan hidup Indonesia pada masa yang akan datang ?

\section{b. Tujuan Penelitian}

Berdasarkan Identifikasi masalah diatas, maka penelitian ini bertujuan untuk

1. Menemukan implikasi apa yang terjadi terkait dimasukkannya penegakan hukum pidana dalam undang-undang nomor 32 tahun 2009 tentang perlindungan dan pengelolaan lingkungan hidup terhadap penegakan hukum lingkungan di Indonesia saat ini.

2. Menemukan implikasi apa yang terjadi terkait dimasukkannya penegakan hukum pidana dalam undang-undang nomor 32 tahun 2009 (tentang perlindungan dan pengelolaan lingkungan hidup) dan RUU KUHP terhadap penegakan hukum lingkungan di Indonesia pada masa yang akan datang.
Penelitian ini diharapkan dapat berguna :

1. Secara teoritis : semoga dapat menjadi salah satu sumbang fikir untuk menambah literatur sekaligus khazanah ilmu hukum secara umum dan ilmu hukum tata negara secara khusus terlebih untuk bidang politik hukum dan hukum lingkungan.

2. Secara praktis : semoga penelitian ini mampu memberikan masukan, sumbang fikir sekaligus bisa memberi pengaruh positif kepada semua stake holders sehingga mampu mengimplementasikan peraturan peraturan perundang-undangan terkait pengelolaan lingkungan hidup dengan baik dan benar, terutama harus baik dan benar mengartikan ketentuanketentuan penegakan hukum pidana dalam UUPPLH sehingga tidak terjadi kecurangan-kecurangan. Sehingga akan bermuara kepada keberpihakan kita kepada lingkungan hidup Indonesia.

\section{Tinjauan Pustaka}

\section{a. Politik Hukum}

Sudah banyak pengertian atau definisi tentang politik hukum yang diberikan oleh para ahli di dalam berbagai literatur. Berikut Penulis jabarkan beberapa pengertian Politik Hukum menurut para ahli :

\section{c. Kegunaan Penelitian}


1. Menurut David Kairsy ${ }^{6}$, politik hukum merupakan kebijaksanaan negara untuk menerapkan hukum.

2. Teuku Muhammad Radhie $^{7}$ mengkonsepsi politik hukum sebagai pernyataan kehendak penguasa negara mengenai hukum yang berlaku di wilayah suatu Negara dan mengenai arah kemana hukum hendak dikembangkan.

3. Moh. Mahfud MD menyatakan bahwa :

Politik hukum adalah legal policy yang akan atau telah dilaksanakan secara nasional oleh Pemerintah Indonesia; mencakup pula pengertian tentang bagaimana politik memengaruhi hukum dengan cara melihat konfigurasi kekuatan yang ada dibelakang pembuatan dan penegakan hukum itu.Disini hukum tidak dapat hanya dipandang sebagai pasal-pasal yang bersifat imperative atau keharusan-keharusan yang bersifat das sollen, melainkan harus dipandang sebagai subsistem yang dalam kenyataan (das sein) bukan tidak mungkin sangat ditentukan oleh politik, baik dalam perumusan materi

${ }^{6}$ David Kairsy (ed). The Politics of Law, A Progressive Critique, Pantheon Books, New York, 1990, h. xi

7 Teuku Muhammad Radhie dalam majalah PRISMA, no. 6 tahun keI-II, Desember 1973 dan pasal-pasalnya maupun dalam implementasi dan penegakannya. ${ }^{8}$

Berdasar pengertian tersebut menurut Moh. Mahfud terlihat politik hukum mencakup proses pembuatan dan pelaksanaan hukum yang dapat menunjukkan sifat dan ke arah mana hukum dibangun dan ditegakkan. ${ }^{9}$

4. Mantan Ketua Perancang Kitab Undang-Undang Hukum Pidana (KUHP) Soedarto mengemukakan bahwa politik hukum adalah kebijakan negara melalui badan-badan negara yang berwenang untuk menetapkan peraturan-peraturan yang dikehendaki yang diperkirakan akan dipergunakan untuk mengekspresikan apa yang terkandung dalam masyarakat dan untuk mencapai apa yang dicitacitakan. $^{10}$

Berdasarkan pengertian tentang konsepsi politik hukum di atas, dalam kajian ini politik hukum dimaksudkan sebagai kebijakan hukum yang menjadi dasar dari pengelolaan lingkungan hidup di Indonesia. Berbicara mengenai kebijakan hukum tentu UUD 1945 sebagai basic norm menjadi rujukan pertama, termasuk dalam pengelolaan lingkungan hidup dan sumber daya alam.

${ }^{8}$ Mahfud MD, Politik Hukum di Indonesia, Rajawali Pers, Jakarta, edisi revisi, cetakan ke-5, 2012, h. 9-10

${ }^{9}$ Ibid

10 Soedarto, Hukum dan Hukum Pidana, Alumni, Bandung, 1986, h.151 
Karena itu, dalam melihat persoalan hukum di Indonesia harus dipandang dari kenyataan sejarah dan perkembangan hukum Indonesia itu. Pada saat sekarang ini terdapat perbedaan cara pandang terhadap hukum diantara kelompok masyarakat Indonesia. Berbagai ketidakpuasan atas penegakkan hukum dan penanganan berbagai persoalan hukum bersumber dari cara pandang yang tidak sama tentang apa yang dimaksud hukum dan apa yang menjadi sumber hukum.

\section{b. Politik Hukum Lingkungan Indonesia}

Sebelum adanya perubahan kedua dan keempat UUD 1945, satu-satunya ketentuan konstitusi yang menjadi landasan hukum bagi pengelolaan lingkungan dan sumber daya alam adalah Pasal 33 ayat (3), yang lebih banyak ditafsirkan sebagai pemanfaatan dan ekploitasi sumber daya alam dengan justifikasi untuk mencapai kesejahteraan rakyat, sehingga aspek perlindungan dan keberlanjutan lingkungan dan sumber daya alam menjadi terabaikan.

Perubahan kedua dan keempat UUD 1945, telah memasukkan ketentuan baru terkait dengan pengelolaan lingkungan hidup dan pemanfaatan sumber daya alam, yaitu Pasal $28 \mathrm{H}$ ayat (1) dan Pasal 33 ayat (4) dan (5) UUD 1945. Pasal 28H ayat (1) menyatakan bahwa "setiap orang berhak hidup sejahtera lahir dan batin, bertempat tinggal, dan medapatkan lingkungan hidup baik dan sehat serta berhak memperoleh pelayanan kesehatan." Pasal 33 ayat 4 UUD 1945 "Perekonomian nasional diselenggarakan berdasar atas demokrasi ekonomi dengan prinsip kebersamaan, efisiensi berkeadilan, berkelanjutan, berwawasan lingkungan, kemandirian, serta dengan menjaga keseimbangan kemajuan dan kesatuan ekonomi nasional." Sementara Pasal 33 ayat (5) menegaskan bahwa ketentuan lebih lanjut diatur dengan undang-undang.

Dari ketentuan Pasal 28H ayat (1), Pasal 33 ayat (3), (4) dan (5) UUD 1945, terdapat 5 hal penting yang menjadi kebijakan hukum negara dalam pengelolaan lingkungan hidup dan pemanfaatan sumber daya alam, adalah : ${ }^{11}$

1. Pengelolaan lingkungan dan pemanfaatan sumber daya alam harus diletakkan dalam kerangka pengakuan, perlindungan dan pemenuhan hak asasi setiap warga Negara atas lingkungan hidup yang baik dan sehat. Dengan kata lain hak asasi atas lingkungan hidup yang baik dan sehat tidak dapat dikorbankan akibat pelaksanaan pembangunan dan

${ }^{11}$ Edra Satmaidi, Politik Hukum Pengelolaan Lingkungan Hidup Indonesia, Makalah, 2010, h. 18 
David Aprizon Putra: Implikasi Politik Penegakan Hukum Pidana Dalam Undang-Undang Nomor 32 Tahun 2009tentang Perlindungan Dan Pengelolaan Lingkungan Hidup Terhadap Upaya Penegakan Hukum Lingkungan Hidup

pemanfaatan sumber daya alam.

2. Pengelolaan lingkungan hidup dan pemanfaatan sumber daya alam merupakan tanggung jawab negara, di mana melalui hak menguasai negara, negara membuat aturan-aturan dan kebijakan pemanfaatan lingkungan dan sumber daya alam.

3. Kesejahteraan rakyat menjadi dasar filosofis dan sosiologis bagi segala aktivitas dan kegiatan pengelolaan lingkungan hidup dan pemanfaatan sumber daya alam dipergunakan bagi kesejahteraan rakyat.

4. Pengelolaan lingkungan hidup dan pemanfaatan sumber daya alam merupakan sarana untuk mencapai pembangunan berkelanjutan berwawasan lingkungan hidup, dalam arti sasaran pengelolaan lingkungan hidup dan pemanfaatan sumber daya alam tidak saja mencakup kesejahteraan rakyat, melainkan juga aspek keberlanjutan lingkungan hidup dan kemajuan ekonomi nasional.
5. Adanya

pendelegasian

pengaturan lebih lanjut

mengenai pengelolaan

lingkungan hidup dengan

undang-udang.

UU Nomor 4 tahun 1982 tentang Pengelolaan Lingkungan Hidup adalah produk hukum pertama yang dibuat oleh Indonesia terkait legislasi lingkungan hidup Indonesia. Selain undang-undang kebijakan-kebijakan hukum sangat memegang peranan penting dalam upaya pelaksanaan penegakan hukum lingkungan. Sejak diundangkannya UU 4/1982, berbagai produk peraturan perundang-undangan resmi telah berhasil ditetapkan sebagai kebijakan yang diharapkan dapat dijadikan pegangan dalam setiap rangka dan gerak pembangunan dilakukan, baik oleh pemerintah, masyarakat maupun badanbadan usaha. Beberapa peraturan tersebut menurut Jimly Asshiddiqie ${ }^{12}$ adalah :

1. Undang-undang tentang Pengelolaan Lingkungan Hidup Nomor 23 tahu 1997 (Lembaran Negara Republik Indonesia Tahun 1997 Nomor 68, Tambahan Lembaran Negara Nomor 3699)

12 Jimly asshiddiqie, Green Constitution : Nuansa Hijau Undang-Undang Dasar Negara Republik Indonesia Tahun 1945, Rajawali Pers, Jakarta, 2010, h. 161 
AL-IMARAH: Jurnal Pemerintahan dan Politik Islam Vol. 3, No. 1, 2018

2. Peraturan Pemerintah Nomor 52 tahun 2008 tentang Jenis dan Tarif Penerimaan Negara Bukan Pajak yang berlaku pada Kementerian Negara Lingkungan Hidup (Lembaran Negara Republik Indonesia Tahun 2008 Nomor 110, Tambahan Lembaran Negara Nomor 4882)

3. Peraturan Pemerintah Nomor 40 tahun 2003 sebagai pelaksanaan UU tentang Tarif atas Jenis Penerimaan Negara Bukan Pajak yang berlaku pada Kementerian Negara Lingkungan Hidup dibidang Pengendalian Dampak lingkungan (Lembaran Negara Republik Indonesia Tahun 2003 Nomor 81, Tambahan Lembaran Negara Nomor 4303)

4. Peraturan Pemerintah Nomor 4 tahun 2001 sebagai tentang Pengendalian Kerusakan dan atau Pencemaran Lingkungan Hidup yang berkaitan dengan kebakaran hutan dan atau lahan (Lembaran Negara Republik Indonesia Tahun 2001 Nomor 10, Tambahan Lembaran Negara Nomor 4076)
5. Peraturan Pemerintah Nomor 54 tahun 2000 tentang Lembaga Penyedia Jasa Layanan Penyelesaian Sengketa Lingkungan Hidup diluar Pengadilan (Lembaran Negara Republik Indonesia Tahun 2000 Nomor 113, Tambahan Lembaran Negara Nomor 3982)

UU No. 32 Tahun 2009 tentang Perlindungan dan Pengelolaan Lingkungan Hidup sebagai pengganti UU No. 23 Tahun 1997 membawa perubahan mendasar dalam pengaturan pengelolaan lingkungan hidup di Indonesia. Karena dilihat dari judul UU No. 32 Tahun 2009 adanya penekanan pada upaya perlindungan lindungan hidup yang diikuti dengan kata pengelolaan lingkungan hidup. Padahan dari segi kaidah bahasa, dalam kata pengelolaan telah termasuk didalamnya kegiatan atau aktivitas perlindungan. Dengan adanya penekanan pada upaya perlindungan, disamping kata pengelolaan lingkungan hidup, UU 32 Tahun 2009 memberikan perhatian serius pada kaidah-kaidah pengaturan yang bertujuan memberikan jaminan bagi terwujudnya pembangunan berkelanjutan dan memastikan lingkungan hidup dapat terlindungi dari usaha atau kegiatan yang 
menimbulkan kerusakan atau pencemaran lingkungan hidup.

Dikaitkan dengan pendapat Teuku Muhammad Radhie mengenai politik hukum sebagai arah (tujuan) kemana hukum hendak dikembangkan, maka UU No. 32 Tahun 2009 menetapkan arah (tujuan) kemana hukum perlindungan dan pengelolaan lingkungan hidup hendak dikembangkan. Menurut Pasal 3 UU 32 tahun 2009, perlindungan dan pengelolaan lingkungan hidup bertujuan:

1. melindungi wilayah Negara Kesatuan Republik Indonesia dari pencemaran dan/atau kerusakan lingkungan hidup;

2. menjamin keselamatan, kesehatan, dan kehidupan manusia;

3. menjamin kelangsungan kehidupan makhluk hidup dan kelestarian ekosistem;

4. menjaga kelestarian fungsi lingkungan hidup;

5. mencapai keserasian, keselarasan, dan keseimbangan lingkungan hidup;

6. menjamin terpenuhinya keadilan generasi masa kini dan generasi masa depan;

7. menjamin pemenuhan dan perlindungan hak atas lingkungan hidup sebagai bagian dari hak asasi manusia;
8. mengendalikan pemanfaatan sumber daya alam secara bijaksana;

9. mewujudkan pembangunan berkelanjutan; dan

10. mengantisipasi isu lingkungan global.

Untuk mencapai tujuan di atas, UU No. 32 Tahun 2009 menetapkan sejumlah instrumen hukum pencegahan pencemaran dan atau kerusakan lingkungan hidup yaitu Kajian Lingkungan Hidup Strategis (KLHS), Tata Ruang, Baku Mutu Lingkungan Hidup, Kriteria Baku Kerusakan Lingkungan Hidup, AMDAL, Upaya Pengelolaan Lingkungan Hidup dan Upaya Pemantauan Lingkungan Hidup (UKL-UPL), Perizinan, Instrumen Ekonomis Lingkungan, Peraturan Perundang-undangan Berbasiskan Lingkungan Hidup, Anggaran Berbasiskan Lingkungan Hidup, Analisis Risiko Lingkungan Hidup, Audit Lingkungan Hidup, dan instrument lain sesuai kebutuhan dan perkembangan ilmu pengetahuan, dimana KLHS menempati posisi puncak dalam pencegahan dan pencemaran lingkungan hidup. Penekanan pada aspek perlindungan lingkungan hidup, juga terlihat dari adanya dua tingakatan izin yang harus dipenuhi oleh setiap orang atau pelaku usaha/kegiatan yang terkait dengan pengelolaan lingkungan hidup yaitu adanya kewajiban 
memperoleh izin lingkungan terlebih dahulu sebagai syarat untuk mendapat izin usaha dan/atau kegiatan. Di samping instrument pencegahan, juga diatur instrument penegakan hukum (administrasi, perdata, dan pidana) beserta penerapan sanksi administrasi, ganti rugi dan sanksi pidana.

Penetapan UU 32 Tahun 2009 berusaha memastikan adanya perlindungan dan pengelolaan lingkungan hidup secara berkelanjutan dan berwawasan lingkungan hidup sedini mungkin yaitu melalui dari tingkat kebijakan, rencana dan program pembangunan (KLHS), maupun pada kajian lingkungan hidup bagi kegiatan atau usaha seperti telah dikenal selama ini, melalui mekanisme AMDAL. Salah satu paian tujuan penegakan hukum lingkungan adalah pencapaian pembangunan negara. Kompleksitas pembangunan negara/pembangunan nasional sangat dipengaruhi oleh banyak faktor, salahs atu faktor yang memegang peranan sentral tentunya adalah terkait eksistensi hukum. Sebagaimana Mochtar memberikan pandangannya terkait hal itu adalah pemikiran beliau terkait memulai pembangunan nasional dari pembinaan hukum terlebih dahulu. Dalam rangka pembinaan hukum dalam rangka pembangunan nasional, menurut beliau ada tiga kelompok masalah yang akan dihadapi, yaitu: ${ }^{13}$

1. Dokumentasi dan Kepustakaan Hukum, yang terdiri dari:

a. Dokumentasi, seperti bahan-bahan perundang-undangan; risalahan DPR, UU, dan produk legislatif lainnya, kumpulan keputusan pengadilan negeri, pengadilan tinggi, MA dan risalahnya; kumpulan perjanjian dan traktat;

b. Publikasi, moografi, tulisan-tulisan ahli hukum, majalah-majalah hukum

c. Perpustakaan, yakni parlemen, pemerintah, pengadilan, dan fakultas-fakultas hukum.

2. Media dan personil (unsur manusia)

a. Media yaitu bahasa dan hukum, kamus dan kompendium hukum; pendidikan hukum

b. Personil yaitu ]ahli hukum dan penerapan hukum

3. Perkembangan Hukum Nasional

Dalam upaya penegakan hukum lingkungan, maka ketiga faktor tersebut akan sangat berpengaruh dalam perjalannya politik hukumnya nanti. Diperlukan dasar hukum yang kuat untuk menjadikan negara Indonesia sebagai

13 Mochtar Kusumaatmadja, Konsep-Konsep Hukum Dalam Pembangunan, Alumni, Bandung, 2011, h.2 
David Aprizon Putra: Implikasi Politik Penegakan Hukum Pidana Dalam Undang-Undang Nomor 32 Tahun 2009tentang Perlindungan Dan Pengelolaan Lingkungan Hidup Terhadap Upaya Penegakan Hukum Lingkungan Hidup

negara hukum yang kuat, yaitu dimulai dari pembinaan hukum nasional yang benar-benar kuat pula dari dasarnya.

c. Penegakan Hukum Pidana Dalam Undang-Undang Nomor 32 Tahun 2009 Tentang Perlindungan Dan Pengelolaan

\section{Lingkungan Hidup}

Dalam Kabinet Indonesia Bersatu jilid II yang dinahkodai oleh Susilo Bambang Yodoyono dan Budiono ini upaya untuk melakukan penegakan hokum lingkungan dan penanganan berbagai kasus lingkungan belum menunjukkan hasil menggembirakan. Pemerintah oleh kalangan aktivis lingkungan dinilai hanya mengurusi masalah politik dan sibuk mengurusi partai tanpa ada keberpihakan pada lingkungan. Akibatnya persoalan lingkungan, seperti kasus pencemaran Buyat,illegal loging, kebakaran hutan pencemaran dan perusakan lingkungan disejumlah daerah tidak dapat ditangani secara tuntas. Kebijakan pemerintah yang tidak memihak pada lingkungan berakibat pada terjadinya musibah yang terus terjadi secara beruntun di berbagai tempat hampir di seluruh wilayah Indonesia. Gambaran tersebut menunjukan adanya indikasi bahwa bekerjanya lembaga pengadilan dan penegakan hukum lingkungan di Indonesia masih amat dipengaruhi kepentingan politik. $^{14}$ Undang-undang Nomor 32 Tahun 2009 tentang Perlindungan dan Pengelolaan Lingkungan Hidup (UUPPLH) mengatur permasalahan lingkungan sebagai dasar pedoman bagi aparat penegak hukum untuk menjerat pelaku tindak pidana lingkungan dikenakan hukuman pidana sesuai aturan yang berlaku. Pasal 1 angka 16, menyatakan definisi perusakan lingkungan hidup adalah :

Tindakan orang yang menimbulkan perubahan langsung atau tidak langsung terhadap sifat fisik, kimia,dan atau hayati lingkungan hidup sehingga melampaui ktriteria baku kerusakan lingkungan hidup.

Pasal 1 angka 17 juga menyatakan bahwa kerusakan lingkungan hidup adalah

Perubahan langsung dan/atau tidak langsung terhadap sifat fisik, kimia, dan/atau hayati lingkungan hidup yang melampaui kriteria baku kerusakan lingkungan hidup.

Dengan demikian di dalam undang-undang ini, perbuatan yang menimbulkan pencemaran lingkungan dan atau perusakan lingkungan hidup yang dilakukan dengan sengaja atau tidak

14 Absori, Penegakan Hukum Lingkungan Pada Era Reformasi, artikel dalam Jurnal Ilmu Hukum, Vol. 8. No. 2, September 2005, h. 10 
sengaja atau kealpaan diarahkan menjadi perbuatan tindak pidana yang dalam undang-undang ini merupakan kejahatan (Pasal 97 UUPPLH).

Sesuai Pasal 71 ayat (1) Menteri, gubernur, atau bupati/walikota sesuai dengan kewenangannya wajib melakukan pengawasan terhadap ketaatan penanggung jawab usaha dan/atau kegiatan atas ketentuan yang ditetapkan dalam peraturan perundangundangan di bidang perlindungan dan pengelolaan lingkungan hidup. Ayat (2) Menteri, gubernur, atau bupati/walikota dapat mendelegasikan kewenangannya dalam melakukan pengawasan kepada pejabat/instansi teknis yang bertanggung jawab di bidang perlindungan dan pengelolaan lingkungan hidup. Ayat (3) Dalam melaksanakan pengawasan, Menteri, gubernur, bupati/walikota menetapkan pejabat pengawas lingkungan hidup yang merupakan pejabat fungsional.

Di dalam Pasal 76 UUPPLH ini mengatur tentang sanksi administrasi. Menteri, gubernur, atau bupati/walikota menerapkan sanksi administratif kepada penanggung jawab usaha dan/atau kegiatan jika dalam pengawasan ditemukan pelanggaran terhadap izin lingkungan. Sanksi administratif terdiri atas; teguran tertulis, paksaan pemerintah, pembekuan izin lingkungan atau pencabutan izin lingkungan. Pasal 80 ayat
(1) mengatur tentang paksaan pemerintah kepada penanggung jawab usaha dan/atau kegiatan yang yang melanggar izin lingkungan berupa :

a. penghentian sementara kegiatan produksi,

b. pemindahan sarana produksi,

c. penutupan saluran pembuangan air limbah atau emisi,

d. pembongkaran,penyitaan terhadap barang atau alat yang berpotensi menimbulkan pelanggaran,

e. penghentian sementara seluruh kegiatan,

f. tindakan lain yang bertujuan untuk menghentikan pelanggaran dan tindakan pemulihan fungsi lingkungan hidup.

Pengenaan paksaan pemerintah dapat dijatuhkan tanpa didahului teguran apabila pelanggaran yang dilakukan menimbulkan : a. ancaman yang sangat serius bagi manusia dan lingkungan hidup, b. dampak yang lebih besar dan lebih luas jika tidak segera dihentikan pencemaran dan/atau perusakannya, c. kerugian yang lebih besar bagi lingkungan hidup jika tidak segera dihentikan pencemaran atau kerusakannya ayat (2).

Pasal 87 Undang-Undang No. 32 Tahun 2009 mengatur tentang kewajiban penanggung jawab usaha untuk memberi ganti rugi kepada orang atau lingkungan 
yang dirugikan. Selain korban maka organisasi lingkungan hidup juga dapat meminta pertanggungjawaban perdata kepada pelaku kegiatan usaha (Pasal 92). Akan tetapi apabila gugatan tersebut dilakukan oleh organisasi lingkungan hidup, permintaan yang dapat diajukan hanya sebatas melakukan tindakan tertentu, kecuali biaya atau pengeluaran nyata. Sehingga bagi masyarakat yang menderita kerugian akibat pencemaran dan atau perusakan lingkungan hidup dapat melakukan-gugatan secara bersamasama dengan cara gugatan perwakilan kelompok (Pasal 91).

Hal terpenting dalam melakukan gugatan ini, kelompok masyarakat dapat menempuh cara-cara diluar pengadilan yang dikenal dengan mekanisme alternatif pnyelesaian sengketa. Bab XIV mengatur tentang Penyidikan dan Pembuktian. Selain penyidik pejabat polisi, pejabat pegawai negeri sipil tertentu di lingkungan instansi pemerintah yang lingkup tugas dan tanggung jawabnya di bidang perlingungan dan pengelolaan lingkungan lingkungan hidup diberi wewenang sebagai penyidik sebagai dimaksud dalam hukum acara pidana untuk melakukan penyidikan tindak pidana lingkungan hidup.

Penyidik Pegawai Negeri Sipil berwenang antara lain : 1) melakukan pemeriksaan atas kebenaran laporana atau keterangan berkenaan dengan tindak pidana di bidang perlindungan dan pengelolaan lingkungan hidup. 2) melakukan pemeriksaan terhadap setiap orang yang diduga melakukan tindak pidana di bidang perlindungan dan pengelolaan lingkungan hidup. 3) meminta keterangan dan bahan bukti dari setiap orang berkenaan dengan peristiwa tindak pidana di bidang lingkungan hidup. 4)melakukan pemeriksaan atas pembukuan, catatan, dan dokumen lain merkenaan dengan tindak pidana di bidang lingkungan hidup. 5)melakukan penyitaan terhadap bahan dan barang hasil pelanggaran yang dapat dijadikan bukti dalam perkara tindak pidana lingkungan hidup. 6) meminta bantuan ahli dalam rangka tugas penyidikan. 7) menghentikan penyidikan. 8) melakukan penggeledahan terhadap badan, pakaian, ruangan atau tempat lain yang diduga merupakan tempat dilakukannya tindak pidana atau menangkap dan menahan pelaku tindak pidana.

Adapun untuk pembuktian diatur dalam Pasal 96, alat bukti yang sah dalam tuntutan tindak pidana lingkungan terdiri atas; keterangan saksi, keterangan ahli, surat, petunjuk, keterangan terdakwa, alat bukti lain, termasuk alat bukti yang diatur dalam peraturan perundang-undangan. Sistem pembuktian yang harus dilakukan penggugat atau aparat penegak hukum 
merupakan problem pembuktian yang sulit dan pelik selama ini. Karena aparat penegak hukum akan mengalami kesulitan terutama dalam masalah pembuktiannya yang berkaitan dengan hal-hal yang bersifat sangat tehnis untuk menentukan klasifikasi ataupun unsur-unsur yang harus dipenuhi sehingga dikatakan sebagai pelaku tindak pidana lingkungan. Kemudian juga adanya keterbatasan pengetahuan tentang permasalahan, sarana, prasarana, dana maupun pemahaman terhadap substansi hukum karena rata-rata korban adalah orangorang yang berpendidikan rendah dan kondisi ekonominya lemah.

Setelah melihat uraian tentang pembaharuan dan perbedaan substansial terhadap Undang-Undang Nomor 32 Tahun 2009, apakah undang-undang tersebut berlaku efektif dalam menanggulangi permasalahan lingkungan terutama masih sering terjadinya pencemaran air oleh limbah industri atau ada segelintir manusia yang secara sadar masih membuang sampah ke dalam sungai, sehingga sungai tersebut menjadi kotor. Efektivitas hukum dapat dijelaskan sebagai suatu keadaan dimana terjadi kesesuaian antara cita-cita yang terkandung di dalam substansi hukum dengan realitas berlakunya hukum tersebut di dalam masyarakat. Hukum dianggap kurang atau tidak efektif apabila terdapat disparitas antara realita hukum dan ideal hukum, sehingga hukum tersebut harus dirombak dan disusun kembali.

Kalau ideal hukum itu mengacu kepada tujuan atau cita-cita yang terkandung di dalam isi/substansi hukum, realita hukum mengacu kepada pengertian penerapan hukum yang indikatornya adalah kesadaran dan atau kepatuhan hukum yang tercermin dalam perilaku warga masyarakat tersebut. Maka dapat dikatakan bahwa efektivitas hukum yang berlaku dalam suatu masyarakat tidak terlepas dari konsep kesadaran hukum dan atau kepatuhan hukum dari masyarakat itu sendiri. Masih sering terjadinya pencemaran yang dilakukan oleh pihak perusahaan atau industri dan masih rendahnya ketaatan dan kepatuhan serta kesadaran warga masyarakat untuk menjaga lingkungan yag bersih dan sehat menjadi indicator bahwa penegakan hukum terhadap pengelolaan lingkungan yang bersih dan sehat belum berjalan. Dengan demikian secara implementasi efektivitas Undang-undang Nomor 32 Tahun 2009 masih rendah hal ini dikarenakan penegakan hukum terutama dalam masalah pembuktian sulit dilakukan dan pengawasan dalam rangka pengendalian dan pengelolaan lingkungan hidup dapat dikatakan masih jalan ditempat walaupun dari aspek politik 
David Aprizon Putra: Implikasi Politik Penegakan Hukum Pidana Dalam Undang-Undang Nomor 32 Tahun 2009tentang Perlindungan Dan Pengelolaan Lingkungan Hidup Terhadap Upaya Penegakan Hukum Lingkungan Hidup

hukum secara substansial isi /materi hukum lingkungan tersebut telah banyak terjadi perubahan disesuaikan dengan kondisi sosial masyarakat.

\section{Pembahasan}

\section{A. Implikasi Politik Penegakan Hukum} Pidana Dalam Undang-Undang Nomor 32 Tahun 2009 Tentang Perlindungan Dan Pengelolaan Lingkungan Hidup Terhadap Upaya Penegakan Hukum Lingkungan Hidup Indonesia Saat Ini.

Malthus dalam postulatnya meramalkan bahwa kemajuan penduduk untuk bertambah secara kuantitas adalah lebih besar daripada kesanggupan sumber alam menyediakan kebutuhan pangan manusia, sehingga secara matematis dapat dijelaskan pertumbuhan pangan mengikuti deret hitung. ${ }^{15}$ Msalah lingkungan hidup di Indonesia semakin hari semakin mengalami peningkatan sekaligus kompleksitas yang luar niasa peliknya. Lingkungan hidup kalah melawan kekuatan pembangunan yang selalu saja menjadikan tujuan ekonomi diatas segalagalannya. Paradigma kalangan pemerintahan berpendirian bahwa tujuantujuan pembangunan ekonomi tidak perlu dipertentangkan dengan usaha-usaha melestarikan lignkungan hidup. ${ }^{16}$

\footnotetext{
${ }^{15}$ Donella H. Meadows, Batas-batas pertumbuhan, diterjemahkan oleh : Masri Maris, Gramedia, Jakarta, 1980, h.14

${ }^{16}$ Muhammad Erwin, Hukum Lingkungan : dalam sistem
}

Langkah awal yang kemudian menjadi pondasi berpijak sistem hukum lingkungan untuk menjamin tidak terjadinya kerusakan lingkungan yang semakin parah adalah pilihan politik hukum lingkungan kita. Mau diarahkan kemana direksinya, mau dijadikan seperti apa posturnya. Sebagaimana penulis sampaikan pada bagian awal, bahwa menurut Prof.Daud Silalahi untuk menjaga lingkungan hidup Indosia agar terjamin kelestarian serta mutunya adalah dengan memiliki sistem hukum yang kuat. Sistem hukum yang mampu menjawab serta menyelesaikan setiap permasalahan hukum yang terjadi. ${ }^{17}$

Pilihan politik hukum kita terhadap penegakan hukum lingkungan adalah dengan dimasukannya penegakan hukum pidana didalam sistem penegakan hukum lingkungan. Berikut penulis jabarkan secara yuridis terkait dengan pilihan politik hukum tersebut. Sejak dikeluarkannya UUPPLH 2009 yang menggantikan UUPLH 1997 maka fungsi sebagai undang-undang induk umbrella provisions melekat pada UUPPLH 2009. UUPPLH membawa perubahan mendasar dalam pengaturan pengelolaan lingkungan

pembangunanLingkungan Hidup Edisi Ketiga, Refika Aditama, Bandung, 2007, h. 202

\footnotetext{
${ }^{17}$ Penulis sampaikan pada bagian latar
belakang, tepatnya pada paragraf $2 \mathrm{~h} .1$ ${ }^{17}$ Penulis sampaikan pada bagian latar
belakang, tepatnya pada paragraf $2 \mathrm{~h} .1$
} 
hidup di Indonesia. $^{18}$ Jika dicermati terdapat beberapa perbedaan pengaturan antara UUPPLH 1997 dan UUPPLH 2009. Pertama, UUPPLH 1997 merumuskan tindak pidana sebagai tindakan yang mengakibatkan pencemaran dan/atau perusakan lingkungan hidup (sebagaimana diatur dalam Pasal 41),sedangkan UUPPLH 2009 merumuskan tindak pidana yaitu sebagai tindakan yang mengakibatkan dilampauinya baku mutu udara ambien, baku mutu air, baku mutu air laut, atau kriteria baku kerusakan lingkungan hidup (sebagaimana diatur dalam Pasal 98). Kedua, UUPPLH 1997 merumuskan pidana dengan pidana maksimum,sedangkan UUPPLH 2009 merumuskan pidana dengan minimum dan maksimum. Ketiga, UUPPLH 2009 mengatur mengenai hal-hal yang tidak di atur dalam UUPPLH 1997 yaitu di antaranya pemidanaan bagi pelanggaran baku mutu (sebagaimana diatur dalam Pasal 100), perluasan alat bukti, keterpaduan penegakan hukum pidana, dan pengaturan tindak pidana korporasi.

Penjelasan UUPPLH 2009 dijelaskan pula mengenai perbedaan mendasar dengan UUPPLH 1997 adalah

${ }^{18}$ Edra Satmaidi, "Politik Hukum Pengelolaan Lingkungan Hidup Di Indonesia Setelah Perubahan Undang-Undang Dasar 1945”, Jurnal Konstitusi, Vol. 4 No. 1 Tahun 2011,FH Universitas Riau, h. 6981 adanya penguatan yang terdapat dalam Undang-Undang ini tentang prinsipprinsip perlindungan dan pengelolaan lingkungan hidup yang didasarkan pada tata kelola pemerintahan yang baik karena dalam setiap proses perumusan dan penerapan instrument pencegahan pencemaran dan/atau kerusakan lingkungan hidup serta penanggulangan dan penegakan hukum wajib mengintegrasikan aspek transparansi,partisipasi, akuntabilitas, \& keadilan.

UUPPLH 2009, dalam penjelasan umum, memandang hukum pidana sebagai upaya terakhir (ultimum remedium) bagi tindak pidana formil tertentu, sementara untuk tindak pidana lainnya yang diatur selain Pasal 100 UUPPLH 2009,tidak berlaku asas ultimum remedium, yang diberlakukan asas premium remedium (mendahulukan pelaksanaan penegakan hokum pidana). Asas ultimum remedium menempatkan penegakan hukum pidana sebagai pilihan hukum yang terakhir.

Asas subsidaritas yang dimiliki oleh UUPPLH 1997 akhirnya tergantikan oleh asas ultimum remedium. Menurut penulis kedua asa ini adalah sama, hanya terdapat sedikit perbedaan yaitu dalam asas ultimum remedium dipertegas bahwa keberadaan asas ini hanya untuk diberlakukan pada delik formal semata, 
bahkan asas ultimum remedium ini sangat dibatasi hanya pada delik formal tertentu, ${ }^{19}$ tidak terhadap seluruh delik formal. Ketergantungan penerapan hukum pidana disandarkan pada keadaan sanksi administrasi yang telah dijatuhkan tidak dipatuhi, atau pelanggaran dilakukan lebih dari satu kali. Pengancaman pidananya tidak sama atau lebih ringan dari batas maksimum pidana yang diatur dalam KUHP, dan khususnya dalam Pasal 97 sampai dengan Pasal 115 UUPPLH 2009, sebenarnya tetap dimungkinkan/diperbolehkan pidana lebih ringan. Hal ini menyebabkan kebingungan dalam penegakan hukum pidana lingkungan hidup, terlebih dalam putusan hakim dalam upaya penjeraan si pelaku (deterrence effect). Penegakan hukum lingkungan di Indonesia mencakup penataan dan penindakan (compliance and enforcement.$^{20}$

Penegakan hukum lingkungan dalam arti yang luas, yaitu meliputi preventif dan represif. Pengertian preventif sama dengan compliance yang

\footnotetext{
${ }^{19}$ Terbatasnya asas ultimum remedium hanya pada delik tertentu yaitu pelanggaran terhadap baku mutu udara ambien, baku mutu air, baku mutu air laut atau kriteria baku kerusakan lingkungan hidup (Pasal 98 UUPPLH 2009) menurut penulis justru suatu kemunduran dari upaya kita untuk menciptakan sistem hukum lingkungan hidup Indonesia yang kuat. Dan juga sebagai bentuk kemunduran dalam pilihan politik hukum lingkungan hidup Indonesia.

${ }^{20}$ Daud Silalahi, Manusia Kesehatan dan Lingkungan, Jurnal Masalah Lingkungan Hidup, Mahkamah Agung RI,1994, h. 1
}

meliputi negosiasi, supervise, penerangan, nasihat), sedangkan represif meliputi penyelidikan, penyidikan sampai pada penerapan sanksi baik administratif mau pun pidana. $^{21}$ Penegakan hukum pengelolaan lingkungan hidup saat ini masih sulit dilakukan oleh karena sulitnya pembuktian dan menentukan kriteria baku kerusakan lingkungan. ${ }^{22}$ Upaya penegakan hukum lingkungan hidup melalui hokum pidana adalah bagaimana tiga permasalahan pokok dalam hukum pidana ini dituangkan dalam undang-undang yang sedikit banyak mempunyai peran untuk melakukan rekayasa social (social engeneering) ${ }^{23}$, yaitu yang meliputi perumusan tindak pidana (criminal act), pertanggungjawaban pidana, dan sanksi (sanction) baik pidana maupun tata-tertib. Sesuai dengan tujuan yang tidak hanya sebagai alat ketertiban,hukum lingkungan mengandung pula tujuan pembaharuan masyarakat (social engineering). Hukum sebagai alat rekayasa sosial sangat penting dalam hukum lingkungan. ${ }^{24}$

21 Dyah Adriantini Sintha Dewi, Konsep Pengelolaan Lingkungan Hidup, Menuju Kemakmuran Masyarakat, Jurnal Fakultas Hukum, Vol. 1 No. 1 Tahun 2012, Universitas Muhammadiyah Magelang

${ }^{22}$ Sutrisno, Politik Hukum Perlindungan dan Pe-ngelolaan Lingkungan Hidup, Jurnal Hukum, No. 3 Vol. 18 Juli 2011, FH UII, h. 444-464

${ }^{23}$ Nyoman Serikat Putra Jaya, 2005, Kapita Selekta Hukum Pidana, Semarang: Badan Penerbit UNDIP, h. 253

${ }^{24}$ Helmi, Hukum Lingkungan dalam Negara Hukum Kesejahteraan Untuk Mewujudkan 
Tindak pidana lingkungan hidup diatur dalam $\mathrm{Bab} \mathrm{XV}$, yang terdiri dari 23 pasal, dimulai dari Pasal 97 sampai dengan Pasal 120 UUPPLH. Dalam Pasal 97 disebutkan, bahwa tindak pidana sebagaimana dimaksud pada Bab XV itu adalah kejahatan. Dengan demikian, mengenai kejahatan terhadap lingkungan hidup diatur dalam bab tersebut. Di samping dalam UUPPLH, kejahatan terhadap lingkungan hidup juga diatur dalam Kitab Undang-Undang Hukum Pidana (KUHP), misalnya dalam Pasal 187, Pasal 188, Pasal 202, Pasal 203, Pasal 502, dan Pasal 503 KUHP.

Kejahatan terhadap lingkungan hidup juga terdapat dalam peraturan perundangundangan di luar KUHP dan diluar UUPLH. Misalnya (antara lain) dalam: Pasal 52 ayat (1) UU No. 5 Tahun 1960 Tentang Peraturan Dasar Pokokpokok Agraria/UUPA; Pasal 31 UU No. 11 Tahun 1967 Tentang Pertambangan; Pasal 11 UU No. 1 Tahun 1973 Tentang Landasan Kontinen Indonesia; Pasal 15 UU No. 11 Tahun 1974 Tentang Pengairan; Pasal 16 ayat (1) UU No. 5 Tahun 1983 Tentang Zona Ekonomi Ekslusif (ZEE) Indonesia; Pasal 27 UU No. 5 Tahun 1984 Ten-tang Perindustrian; Pasal 24 UU No. 9 Tahun 1985 Tentang Perikanan; Pasal 40 UU No. 5 Tahun 1990

Pembangunan Berkelanjutan,Inovatif; Jurnal Ilmu Hukum, Vol 4. No. 5 Tahun 2011, h. 93-103
Tentang Konservasi Sumber Daya Alam Hayati dan Ekosistemnya; Pasal 78 UU No.41 Tahun 1999 Tentang Kehutanan; dan Pasal 94 ayat (1) dan (2) jo. Pasal 95 ayat (1) dan (2) UU No. 7 Tahun 2004 Tentang Sumber Daya Air.

Kejahatan atau tindak pidana lingkungan hidup terdapat dalam berbagai peraturan perundang-undangan selain UUPLH dan KUHP. Oleh karena itu, kecermatan dari para penegak hukum,terutama penyidik, penuntut umum dan hakim sangat diperlukan dalam menemukan peraturan perundangundangan yang berkaitan dengan tindak pidana lingkungan hidup dalam berbagai macam peraturan perundang-undangan itu. Dengan kata lain, peraturan perundangundangan mana yang akan digunakan, tergantung pada terhadap sumber daya apa tindak pidana lingkungan hidup itu dilakukan. Perlindungan dan pengelolaan lingkungan hidup pada hakikatnya adalah penerapan prinsip-prinsip Kebijakan Hukum Pidana dalam Upaya Penegakan Hukum Lingkungan Hidup ekologi dalam kegiatan manusia terhadap dan atau yang berdimensi lingkungan hidup.

B. Implikasi Politik Penegakan Hukum Pidana Dalam Undang-Undang Nomor 32 Tahun 2009 (Tentang Perlindungan Dan Pengelolaan Lingkungan Hidup) Dan Ruu Kuhp Terhadap Upaya 
David Aprizon Putra: Implikasi Politik Penegakan Hukum Pidana Dalam Undang-Undang Nomor 32 Tahun 2009tentang Perlindungan Dan Pengelolaan Lingkungan Hidup Terhadap Upaya Penegakan Hukum Lingkungan Hidup

Penegakan Hukum Lingkungan Hidup Indonesia Pada Masa Yang Akan Datang.

Uraian dalam bagian ini hanya menyoroti secara normatif tindak pidana lingkungan hidup yang sudah diatur dalam RUU KUHP yang notabene akan menjadi salah satu produk politik hukum dimana didalamnya juga ikut mengatur masalah hukium lingkungan. Ada beberapa catatan atas rumusan tindak pidana lingkungan hidup dalam RUU KUHP. Istilah pencemaran dan perusakan lingkungan dicantumkan dalam Buku I RUU KUHP, dalam Bab tentang Pengertian Istilah. Pasal 192 menentukan bahwa pencemaran lingkungan hidup adalah masuknya atau dimasukkannya makhluk hidup, zat, energi, dan/atau komponen lain ke dalam lingkungan hidup oleh kegiatan manusia sehingga kualitasnya turun sampai ke tingkat tertentu yang menyebabkan lingkungan hidup tidak dapat berfungsi sesuai dengan peruntukannya.

Kemudian, Pasal 200 menentukan bahwa Perusakan lingkungan hidup adalah tindakan yang menimbulkan perubahan langsung atau tidak langsung terhadap sifat fisik dan/atau hayatinya yang mengakibatkan lingkungan hidup tidak berfungsi lagi dalam menunjang pembangunan berkelanjutan Kedua pengertian ini mencantumkan kata lingkungan hidup berkali-kali tetapi tidak ditemukan pengertian apa yang dimaksud dengan lingkungan hidup. Dari segi perumusan dan cakupan pe-ngertian terdapat beberapa catatan.

Pertama, rumusan pasal 200 cukup membingungkan karena di bagian akhir disebut istilah pembangunan berkelanjutan sebagai tujuan pemulihan fungsi lingkungan hidup. Dengan demikian, pasal ini menempatkan pembangunan berkelanjutan sebagai paradigma yang mendasari alasan mengapa perusakan lingkungan hidup dilarang oleh RUU KUHP. Namun, konsep ini sebetulnya masih dalam perdebatan, terutama karena arah pandangnya yang masih kuat mendukung keistilahan pembangunan. Pembangunan berkelanjutan merupakan suatu gagasan melestarikan lingkungan hidup untuk mendukung dan melegitimasi berkembangnya pertumbuhan ekonomi kapitalis, sehingga sesungguhnya yang dilestarikan adalah pembangunan dan pertumbuhan ekonomi kapitalis itu sendiri.

Kedua, cakupan tindak pidana lingkungan hidup diatur di dalam Buku II Bab VIII pasal 384 sampai 390 RUU KUHP. Pengaturan tersebut berada di bawah bab tentang tindak pidana yang membahayakan kepentingan umum bagi orang, kesehatan, barang dan lingkung-an 
AL-IMARAH: Jurnal Pemerintahan dan Politik Islam Vol. 3, No. 1, 2018

hidup. Dalam pengaturan tersebut dimasukkan generic crimes (kejahatan umum) yakni pencemaran dan perusakan lingkungan hidup (Pasal 384 dan 385) yang sifatnya kejahatan murni. Namun, RUU KUHP belum memasukan pasalpasal kejahatan dan jenis pidana yang berhubungan dengan pemanfaatan dan pengelolaan sumber daya alam seperti terdapat dalam UU Pertambangan,UU Minyak dan Gas Bumi, UU Sumber Daya Air, UU Kehutanan, UU Konservasi Sumber Daya Alam Hayati dan Ekosistemnya UU Pokok Agraria, UU Perkebunan. Alasan belum dimasukkannya sejumlah tindak pidana yang berhubungan dengan pemanfaatan dan pengelolaan sumber daya alam adalah karena tindak pidana tersebut masuk dalam kategori tindak pidana administrasi, bukan generic crimes. Jika jenisjenis tindak pidana ini dipaksakan masuk dalam RUU KUHP maka kodifikasi ini akan sangat tebal sehingga justru menjadi tidak efisien bagi sebuah kitab pidana.

Perumusan pasal tindak pidana lingkungan hidup dalam RKUHP adalah pola perumusan pasal untuk tindak pidana materil. Dalam rumusan seperti itu tidak ada pembedaan kejahatan berdasarkan akibatnya, sehingga Pasal 384 dan Pasal 385 menyamakan sanksi bagi pencemaran/perusakan lingkungan yang berdampak kecil dengan 
Perumusan ini cukup tegas menguraikan wujud perbuatan, tetapi masih belum jelas apa saja ukuran dan penggolongan jenis bahan. Dalam penjelasan Pasal 390 sebetulnya sedikit menjabarkan tentang cakupan bahan. Di sana dikatakan bahwa: "yang dimaksud dengan 'bahan' tidak saja bahan makanan, tetapi juga meliputi kosmetika, pembersih rumah tangga,dan lain sebagainya". Rumusan ini hanya mampu menjerat perbuatan "memasukkan bahan" tetapi belum sampai ke penggolongan jenis bahan berdasarkan akibat yang ditimbulkannya. Potensi akibat yang muncul dari rumusan ini adalah pelaku yang menimbulkan akibat berdampak sangat ringan terhadap nyawa dan/atau kesehatan manusia memiliki ancaman yang sama dengan pelaku yang secara kategori ilmiah menggunakan bahan yang daya rusaknya sangat besar dan meluas baik bagi lingkungan hidup maupun bagi kesehatan dan/atau nyawa manusia.

Rumusan seperti itu harusnya akan lebih tepat jika diikuti oleh lampiran tentang kategori bahan sebagaimana terdapat dalam Peraturan Pemerintah No. 19 Tahun 1999 tentang Pengelolaan Limbah Bahan Berbahaya dan Beracun. Dalam PP ini daftar limbah berbahaya diberi kode limbah D220, D221, D222 dan D-223. Jika ada bahan yang muncul di luar daftar tersebut maka kategorinya adalah mudah meledak,mudah terbakar, bersifat reaktif, beracun, menyebabkan infeksi dan bersifat korotif. Artinya, ukuran berbahaya hanya satu di antara sekian jenis ukuran lainnya.

Ada beberapa hal yang belum dicantumkan RUU KUHP dalam ruang lingkup tindak pidana lingkungan hidup. Pertama, menurut Pasal 384 ayat (2), 385 ayat (2), 386 ayat (2) dan 387 ayat (2), pidana dengan pemberatan hanya ditujukan terhadap perbuatan yang mengakibatkan orang mati atau luka berat. Sementara akibat perbuatan bagi lingkungan hidup yang secara ilmilah kategorinya adalah perusakan/pencemaran berat, tidak ditempatkan sebagai pidana lingkungan dengan pemberatan.

Kedua, denda yang dicantumkan dalam semua pasal di atas adalah denda karena perbuatan yang mencemari/merusak lingkungan, membahayakan nyawa atau kesehatan dan menyebabkan matinya orang. Sementara biaya social dan ekonomi seperti nilainilai lokal yang hancur karena lingkungan yang rusak dan pendapatan yang berkurang karena pencemaran lingkungan tidak dihitung sebagai ongkos social yang harus digantikan oleh pelaku tindak pidana. Barda Nawawi ${ }^{25}$ dalam

\footnotetext{
${ }^{25}$ Barda Nawawi Arief, "Masalah Penegakan Hukum Pidana Terhadap Tindak Pidana
} 
komentarnya terhadap tindak pidana lingkungan hidup pernah menulis bahwa dampak pencemaran lingkungan tidak hanya fisik tetapi juga nonfisik, termasuk sosial budaya. Tetapi, penafsiran tentang kriteria dampak negatif terhadap sosial budaya sangat terbatas dan dogmatis 15 sehingga belum menyentuh ke persoalan kehancuran nilai masyarakat lokal akibat pencemaran/perusakan lingkungan. Kebijakan Hukum Pidana dalam Upaya Penegakan Hukum Lingkungan Hidup Menurut Barda Nawawi ${ }^{26}$, jika tidak ada kriteria yang jelas tentang pencemaran social budaya maka secara luas dikatakan penyebaran paham komunis, penodaan agama atau mengajak orang tidak menganut agama apa pun menimbulkan pencemaran sosial budaya karena orang menjadi tidak beragama merupakan tindakan pencemaran sosial budaya.

Belum dicantumkannya sanksi bagi kerusakan sosial dan ekonomi akan mencederai keadilan lingkungan, yang mencakup semua aspek, termasuk normanorma budaya dan aturan-aturan yang berharga, peraturan-peraturan,kebiasaankebiasaan, kebijakan-kebijakan, dan keputusan-keputusan untuk mendukung komunitas-komunitas yang berkelanjutan, di mana manusia dapat berinteraksi

\footnotetext{
Lingkungan Hidup”, Jurnal Masalah-Masalah Hukum, No. 1 Tahun 1992, h. 24

Barda Nawawi Arief, "Masalah
}

dengan kepercayaan tentang lingkungan mereka yang aman, terpelihara,dan produktif. Padahal menurut RUU KUHP, dalam mempertimbangkan hukum yang akan diterapkan, hakim sejauh mungkin mengutamakan keadilan di atas kepastian hokum (Pasal 12).

Ketiga, tindak pidana lingkungan hidup cenderung berorientasi kepada kasus-kasus lingkungan urban yang sarat dengan pencemaran dari industri, seperti tindakan memasukan bahan ke dalam sumur, pompa air, mata air,atau ke dalam kelengkapan air minum untuk umum atau untuk dipakai oleh atau bersama-sama dengan orang lain, tanah, air per-mukaan dan udara yang menimbulkan atau patut diduga menimbulkan akibat yang berbahaya bagi kesehatan atau nyawa manusia merupakan kejahatan lingkungan yang umum terjadi di lingkungan perkotaan (Pasal 386, 387, 388, 399 RKUHP). Rumusan seperti itu belum menjangkau tindakan seperti kebakaran hutan, pencemaran tanah oleh akar dan zat kimia dari pohon sawit, yang sulit dikategorikan sebagai tindakan memasukan sesuatu baik sengaja maupun tidak sengaja.

Keempat, rumusan sanksi tindak pidana lingkungan hanya mencantumkan dua jenis sanksi yakni penjara dan denda. Dua jenis sanksi lain yakni melakukan perbuatan tertentu dan ganti rugi yang 
David Aprizon Putra: Implikasi Politik Penegakan Hukum Pidana Dalam Undang-Undang Nomor 32 Tahun 2009tentang Perlindungan Dan Pengelolaan Lingkungan Hidup Terhadap Upaya Penegakan Hukum Lingkungan Hidup

sangat vital dalam kasus-kasus pencemaran/perusakan lingkungan hidup belum dicantumkan. Padahal pidana berupa melakukan perbuatan tertentu dapat diarahkan untuk memulihkan kembali fungsi lingkungan yang telah rusak, sedangkan ganti rugi bisa ditujukan untuk mengganti ongkos sosial akibat pencemaran/perusakan lingkungan.

\section{Penutup}

\section{a. Kesimpulan}

1. Ada beberapa impliksai yang muncul akibat dimasukkannya penegakan hukum pidana dalam UUPPLH 2009 terhadap penegakan penegakan hukum lingkungan Indonesia hidup saat ini. Yaitu:

\section{Pertama, UUPPLH 2009} mengenal pelaku tindak pidana selain manusia yaitu badan hukum atau perserikatan, yayasan, atau organisasi lainnya sedangkan menurut KUHP yang menjadi pelaku adalah hanyalah manusia pribadi;

2. Kedua, UUPPLH 2009 di samping menggunakan sanksi pidana pokok dan pidana tambahan seperti dalam KUHP juga menggunakan tindakan tatatertib dalam mempertahankan norma-normanya;

3. Ketiga, rumusan pemidanaan yang kabur dengan penggunaan kata "dan/atau", menyebabkan hakim dapat memilih antara penjatuhan sanksi kumulatif ataupun alternatif;

4. Keempat, UUPPLH 2009 memandang hukum pidana sebagai upaya terakhir (ultimum remedium) bagi tindak pidana formil tertentu, sementara untuk tindak pidana lainnya yang diberlakukan asas premum remedium (mendahulukan pelaksanaan penegakan hukum pidana).

2. Implikasi yang muncul akibat dimasukkannya penegakan hukum pidana dalam UUPPLH 2009 dan RUU KUHP nantinya terhadap penegakan penegakan hukum lingkungan Indonesia hidup pada masa yang akan datang. Terkait dengan pilihan politik hukum yang kita lakukan tersebut, yaang pertama adalah dimasukkannya penegakan hukum pidana dalam UUPPLH 2009 yang memiliki beberapa kelemahan seperti penulis jabarkan pada kesimpulan identifikasi masalah pertama akan semakin rumuit pula nantinya upaya penegakan hukum lingkungan di Indonesia dengan dimasukkannya ketentuan-ketentuan penegakan hukum pidana kedalah KUHP. Dengan menjadikan penegakan hukum pidana lingkungan kedalam 
AL-IMARAH: Jurnal Pemerintahan dan Politik Islam Vol. 3, No. 1, 2018

KUHP maka akan menghilangkan status lex specialis-nya, dan ini akan menambah kerumitan dan kompleksitas dalam upaya mewujudkan penegakan hukum pidana lingkungan Indonesia pada masa yang akan datang.

\section{b. Saran}

1. Ada beberapa saran yang dapat penulis berikan. Pertama, perlunya pembenahan pola pemidanaan dan sanksi pidana dalam UU Pengelolaan Lingkungan hidup yang memiliki nilainilai kepastian hukum dan nilai-nilai keadilan yang ditegakkan oleh semua pihak; dan kedua,perlunya pembenahan pola pemidanaan dan sanksi pidana dalam UU Pengelolaan Lingkungan hidup yang seharusnya sinkron dan konsisten dengan KUHP dan RUU KUHP di masa mendatang.

2. Beberapa kebijakan hukum pidana dalam penegakan hukum lingkungan hidup di masa mendatang yang perlu dilakukan adalah sebagai berikut. Pertama, pola pendekatan pemidanan lingkungan mendatang adalah penjeraan (deterrence approach) atau lazim disebut dengan pendekatan penegakan hukum atau stick approach. Pendekatan ini paling banyak digunakan dalam kebijakan penegakan hukum lingkungan; kedua, upaya pembuktian diarahkan kepada delik formal dimana pembuktian hanya melihat pada unsur kelakuan yang dapat dilihat dengan unsur panca indera, misalnya tindakan pencemaran atau perusakan lingkungan hidup; dan ketiga, pemidanaan diarahkan pada sanksi kumulatif, artinya hakim dapat menjatuhkan seluruh ketentuan pemidanaan dalam undang-undang lingkungan tersebut, baik digabung seluruhnya atau digabung 2 (dua) atau 3 (tiga) saja dan seterusnya.

\section{Pustaka Acuan}

\section{Buku :}

Daud Silalahi, Manusia Kesehatan dan Lingkungan, Jurnal Masalah Lingkungan Hidup, (Jakarta: Mahkamah Agung RI, 1994)

Daud Silalahi. Masalah Pengelolaan Lingkungan Hidup, Edisi Ketiga,(Bandung: Alumni, 2001

David Kairsy, The Politics of Law, A Progressive Critique, (New York: Pantheon Books, 1990)

Donella H. Meadows, Batas-batas pertumbuhan, diterjemahkan oleh : Masri Maris, (Jakarta: Gramedia1980)

Jimly asshiddiqie, Green Constitution : Nuansa Hijau Undang-Undang Dasar Negara Republik Indonesia Tahun 1945, (Jakarta: Rajawali Pers, 2010) 
David Aprizon Putra: Implikasi Politik Penegakan Hukum Pidana Dalam Undang-Undang Nomor 32 Tahun 2009tentang Perlindungan Dan Pengelolaan Lingkungan Hidup Terhadap Upaya Penegakan Hukum Lingkungan Hidup

Mahfud MD, Politik Hukum di Indonesia, (Jakarta: Rajawali Pers, edisi revisi, cetakan ke-5, 2012)

Mochtar Kusumaatmadja, Konsep-Konsep Hukum Dalam Pembangunan, (Bandung: Alumni, 2011)

Muhammad Erwin, Hukum Lingkungan : dalam sistem kebijaksanaan pembangunan Lingkungan Hidup Edisi Ketiga, (Bandung: Refika Aditama, 2007)

Nyoman Serikat Putra Jaya, Kapita Selekta Hukum Pidana, (Semarang: Badan Penerbit UNDIP, 2005)

Soedarto, Hukum dan Hukum Pidana, (Bandung: Alumni, 1986)

Syahrul Machmud, Penegakan Hukum Lingkungan Indonesia, (Yogyakarta: Graha Ilmu, 2011)

\section{Jurnal, Makalah Dan Majalah:}

Dyah Adriantini Sintha Dewi, Konsep Pengelolaan Lingkungan Hidup, Menuju Kemakmuran Masyarakat, Jurnal Fakultas Hukum, Vol. 1 No. 1 Tahun 2012, Universitas Muhammadiyah Magelang

Sutrisno, Politik Hukum Perlindungan dan Pengelolaan Lingkungan Hidup, Jurnal Hukum, No. 3 Vol. 18 Juli 2011, FH UII.

Helmi, Hukum Lingkungan dalam Negara Hukum Kesejahteraan Untuk Mewujudkan Pembangunan
Berkelanjutan,Inovatif; Jurnal Ilmu Hukum, Vol 4. No. 5 Tahun 2011

Barda Nawawi Arief, "Masalah Penegakan Hukum Pidana Terhadap Tindak Pidana Lingkungan Hidup”, Jurnal Masalah-Masalah Hukum, No. 1 Tahun 1992

I.S Susanto, 1992, Pemahaman Kritis Terhadap Realita Sosial, Majalah Masalah-Masalah Hukum, Nomor 9 Tahun

Teuku Muhammad Radhie dalam majalah PRISMA, no. 6 tahun keI-II, Desember 1973

Edra Satmaidi, Politik Hukum Pengelolaan Lingkungan Hidup Indonesia, Makalah, 2010

Absori, Penegakan Hukum Lingkungan Pada Era Reformasi, artikel dalam Jurnal Ilmu Hukum, Vol. 8. No. 2, September 2005

Edra Satmaidi, "Politik Hukum Pengelolaan Lingkungan Hidup Di Indonesia Setelah Perubahan Undang-Undang Dasar 1945”, Jurnal Konstitusi, Vol. 4 No. 1 Tahun 2011,FH Universitas Riau

\section{Peraturan Perundang-Undangan :}

Undang-Undang Dasar Negara Republik Indonesia

Undang-Undang Nomor 4 Tahun 1982 tentang Ketentuan-Ketentuan Pokok Pengelolaan Lingkungan Hidup 
AL-IMARAH: Jurnal Pemerintahan dan Politik Islam Vol. 3, No. 1, 2018

$\begin{array}{rlr}\text { Undang-Undang } & \text { Nomor } 23 & \text { Tahun } 1997 \\ \text { tentang } & \text { Pengelolaan } & \text { Lingkungan } \\ \text { Hidup } & & \end{array}$

Undang-Undang Nomor 32 tahun 2009 tentang Perlidungan dan Pengelolaan Lingkungan Hidup 